\title{
Entangled Economists: Ragnar Frisch and Jan Tinbergen
}

\author{
ERWIN DEKKER \\ Erasmus University Rotterdam
}

\begin{abstract}
It is 50 years since the first Nobel Prize in economics was awarded to Jan Tinbergen and Ragnar Frisch. This article analyzes the collaborations between these pioneers of econometrics which spanned four decades and various subfields in economics, based on records of their correspondence. It is demonstrated that, while Frisch was largely responsible for theoretical breakthroughs, Tinbergen was responsible for making them public and popularizing them. This is especially relevant for understanding the development of econometric models in the 1950s, decision models of the 1950s, and subsequent work on utility measurement. This division of labor is analyzed in relation to the goals they pursued in their research and their respective perfectionistic (Frisch) and pragmatic (Tinbergen) approaches to economic science. Both men shared a sense of deep social responsibility, but differences in their personalities and approaches to science generated important differences in scientific recognition and policy influence. Although they are both widely remembered for helping to turn economics into a quantitative empirical science, this article shows that they were motivated by separate personal and political goals which shaped their scientific approaches.
\end{abstract}

Keywords: Jan Tinbergen, Ragnar Frisch, history of econometrics, Nobel Prize in economics, policy models

JEL Classification: A14, B23, B20, C18

\section{INTRODUCTION}

It is not infrequent that the Nobel Prize in economics is awarded to a duo. On some occasions, the two laureates may share little else than their field of research. In 1974 Hayek, a staunch liberal, shared the Prize with Gunnar Myrdal, critical man of the left. Similarly, in 2013, Eugene Fama, a resolute defender of the rational expectations hypothesis in economics, shared his prize with Robert Shiller, who is famous for his rediscovery of

AUTHOR'S NOTE: The author would like to acknowledge the generous suggestions offered by Ariane Dupont and Marcel Boumans on earlier drafts of this paper, as well as their encouragement to explore the similarities and differences between Frisch and Tinbergen generally. 
the Keynesian notion of animal spirits. At other times, the winners have made the discovery independently of each other, as was the case in 1975, when the Prize was awarded to Tjalling Koopmans and Leonid Kantorovich for the development of the linear programming method for optimal resource allocation. But in no other instance did the Prize go to two individuals whose professional careers so closely overlapped as that of the first winners Ragnar Frisch and Jan Tinbergen.

Frisch was eight years Tinbergen's senior, and perhaps for that reason appeared to be a small step ahead of Tinbergen throughout their long coevolution. But it was Tinbergen who often made the ideas prominent and who developed much more of a public persona. In fact, many of Frisch's most important contributions remained unpublished, appeared only as memoranda from his research institute (or other institutions), and were known only to relevant insiders. Tinbergen's contributions, on the other hand, often became standard reference works. He left little if anything unpublished: even a conservative estimate suggests at least 30 books and about 1,500 articles from his hand (Tinbergen 2003).

In 1926, Ragnar Anton Kittil Frisch coined the term econometrics in his first economic publication. The opening sentence was bold: "In between mathematics, statistics, and economics, we find a new discipline which for lack of a better name, may be called econometrics" (Frisch 1926b, 2). Four years later, he founded the Econometric Society and not much later became editor of the associated journal Econometrica, a post he would hold for twenty-two years. Tinbergen followed swiftly, and though not among the founders of the Society, he did attend the first meeting of the Society in Lausanne in 1931. He reported to his PhD supervisor, Paul Ehrenfest, that he had met some very good people, but one stood out as "the soul of the conference". That was Ragnar Frisch.

During the 1930's, the two made seminal contributions to an endogenous theory of the cycle, and Tinbergen's report for the League of Nations, with its macro-econometric model of the United States, was designed in close conversation with the work of Frisch. After the war, both men led important economic policy institutes. It was again Frisch who made a breakthrough when he 'inverted' the logic of econometric modelling into the logic of economic planning (Andvig 1988; Dupont-Kieffer 2003). But it was Tinbergen's name which became associated with the new methodology of economic policymaking through his seminal book On the Theory of Economic Policy (Tinbergen 1952). The language of policy targets and

\footnotetext{
${ }^{1}$ Jan Tinbergen to Paul Ehrenfest, 26 September 1931, archives Boerhaave ESC 1021.
} 
instruments has become so standard that most could not imagine we ever worked without them. Later in their careers, both men expanded their vision beyond that of their own continent and became increasingly occupied with issues of development planning. Both were involved with the planning efforts in India and later Egypt. Most importantly, perhaps, both were strong believers that economic expertise deserved a prominent place in the modern state. To that end, both were instrumental in the creation of world-class economic institutions. They also were among the very few modern economists who believed that utility could be measured and who attempted to do so.

In 1969, they were both awarded the first Sveriges Riksbank Prize in Economic Sciences in Memory of Alfred Nobel, popularly known as the Nobel Prize in Economics, for their work on the business cycle in the 1930s. If it had not been for a broken thighbone that prevented Ragnar Frisch from attending the ceremony, it would have been the crowning achievement of a lifelong collaboration and entangled career. This article will detail the entanglement of these men who shared both a scientific approach and a deep sense of social responsibility (Frisch 1946; Tinbergen 1970). But it also aims to illustrate how, through their different personalities, they came to occupy quite different positions later in their careers. $^{2}$

\section{ECONOMETRIC ENDEAVORS}

Much of early twentieth century economics was occupied with two major theoretical inquiries: the nature of the business cycle and value theory. Frisch and Tinbergen became best known for their contributions to business cycle theory, but both got their start in the field of value and utility theory. Tinbergen's first economic publication was a defense of the use of mathematics in economics with an application to value theory in marginal and Marxist economics. In fact, this publication attempted to reconcile the two (Tinbergen 1925). In particular, he suggested that economics needed to be quantitative because seemingly fundamental theoretical differences were essentially about the value of particular coefficients: how much the relative elasticities differ between workers and employers. Frisch also explicitly sought to make the theoretical economics of the early twentieth century quantitative. He identified the fields of monetary

\footnotetext{
${ }^{2}$ The author is also working on an article on the work of Jan Tinbergen and his brother Niko Tinbergen. They are unique in that they are the only siblings to have both received a Nobel Prize, and in different fields with rather different methodologies.
} 
theory, production theory, and value theory as prime candidates (Frisch 1926b, 1926a).

Both men came into economics as relative outsiders. Tinbergen completed his training at university with the physicist Paul Ehrenfest. And, although his dissertation extended the analysis of minimum-problems from physics to economics, he was never trained formally in economics and never really had a direct mentor in the field. That being said, Ehrenfest did encourage his economic investigations, and also had some connections in the field (Boumans 1992). Frisch did study economics; but he did so in Oslo, where the field was new and consisted only of a 2-year program. He soon realized that in order to become an economist he needed to study abroad-and during much of the early 1920s Frisch travelled around to come into contact with economists in France, Germany, Great Britain, and the United States. ${ }^{3}$

It is value theory that, early on, intrigued them both. Unlike many later modern economists both Frisch and Tinbergen were defendants of a cardinal notion of utility, which could be measured. Many other economists rejected this assumption and sought to develop an ordinal notion of utility, which consequently was not directly comparable between individuals. Frisch, on the other hand, spent much of his earlier career attempting to measure utility from the demand for sugar and other commodities (Frisch 1932b, 1932a). His idea was that the theoretical measurement of the utility derived from particular goods could lead to a generalized measure of utility (Dupont-Kieffer 2013). This work inspired Tinbergen, who instantly recognized not only the scientific desirability of the measurement of utility, but also the practical implications. If utility could be measured, the ethical notion of justice could be based on scientific measurements. The ideal of justice could be defined in terms of utility rather than income or opportunities. This was preferable since equal outcomes in material goods would, given different circumstances and preferences for individuals, lead to unequal outcomes (Tinbergen 1930). ${ }^{4}$ For both Tinbergen and

\footnotetext{
${ }^{3}$ There is a good description of Frisch's life and work in Bjerkholt (1995), upon which I draw for this article. For the details of Tinbergen, I am drawing upon my own forthcoming intellectual biography of him.

${ }^{4}$ The measurement of utility had another important significance for both men. They both had religious leanings and more generally were concerned with welfare broadly conceived. When the OECD developed standards for the measurement of national income, Frisch sought to mobilize Tinbergen in an effort to include broader concerns than just material production into this statistic. See Frisch to Tinbergen, 8 October 1949. For the correspondence between Frisch and Tinbergen, I am drawing upon the archive at the Nasjonalbiblioteket in Oslo, Box 761A and B: Correspondence from and to Frisch. A
} 
Frisch, early econometrics was as much concerned with the scientific measurement of welfare as it was with the development of quantitative models of economic dynamics. In 1936 Tinbergen could still write to Frisch that: "The task of the econometrician [is] to calculate as exactly as possible and with utmost care, how human well-being, in the material sense of the words as well as in the spiritual sense, can be increased". ${ }^{5}$

The extensive travelling early in his career put Frisch in an ideal position to connect various people who were working on similar topics but who lacked a research community. The founding of the Econometric Society, with the financial help of Alfred Cowles, would help set up such a community. It was at the first meeting of the Econometric Society that Tinbergen and Frisch met for the first time. As the founder of the Society and the central intellectual leader of the new field of econometrics, Frisch recognized Tinbergen's talent and requested one of his articles for the first issue of Econometrica. But the relationship was not yet one of equanimity. Frisch, eight years the senior of Tinbergen, acted more like a mentor to the younger Tinbergen in these first years.

The second meeting of the Econometric Society was planned in Leyden, the home of Paul Ehrenfest. And Tinbergen, ever the educator, had scheduled lectures by both Ehrenfest and Frisch for the meetings. ${ }^{6}$ In the early years, econometrics was not yet clearly defined and both men were actively trying to shape what it entailed. For Frisch, this included developing a standard notation system in the new field. In 1935, an informal committee was formed with this positivist aim, but nothing came of it (although Frisch never abandoned the ambition). ${ }^{7}$

The goal Tinbergen and Frisch pursued most successfully in these early years was the development of a dynamic apparatus for the analysis of the economy. Frisch developed (circa 1929) what is now regarded as a classic distinction between static and dynamic economics, which refers to the tools used in analysis. An analysis is dynamic when it makes use of a variable and its rate of change (or lagged value); when it is not, it is static (Bjerkholt 1995; Bjerkholt and Dupont-Kieffer 2010). During the Leyden

much smaller subset of these letters is also available in the Tinbergen letters project: https://tinbergenletters.eur.nl.

${ }^{5}$ Tinbergen to Frisch, 20 March 1936.

${ }^{6}$ Ehrenfest commits suicide just before the meetings would start (Klein 1958). Ehrenfest was scheduled to lecture on harmonic oscillations.

${ }^{7}$ Frisch to Tinbergen, October 1935. See also the reminiscences of Haavelmo (Jolink and Barendrecht-Tinbergen 1993, 50). 
meeting, they established a so-called dynamic team, consisting of themselves, Charles Roos, Felice Vinci, Jacob Marschak, Henry Schultz, Harold Hotelling, Charles Evans and Michael Kalecki. ${ }^{8}$

Among other things, this involved the exploration of what a dynamic equilibrium is precisely, which Tinbergen explored in relation to expectations (Tinbergen 1933) and Frisch in relation to the business cycle (Frisch 1929, 1936). Quite early in this development, both Tinbergen and Frisch hit upon the idea of formulating a complete dynamic theory of the economy. Frisch, with his knack for coining new terms, called this the exploration of macrodynamics (as opposed to microdynamics). Around 1930, a wider variety of economists were developing dynamic models of particular markets, perhaps most famously the pig market by Hanau (1928). But the goalposts had been moved quickly by Tinbergen and Frisch: the goal was now a dynamic model of the (national) economy as a whole.

It was a project that combined their search for quantification with their dream of a dynamic model. But in both fields, much had to be developed. In the early 1930s, national income accounts had not yet been developed, and therefore the most central variable in most macro-economic models, GDP, was not even available. At their respective research institutes, Tinbergen and Frisch did much to improve the statistical material. In the meantime, they were already using whatever meagre statistical material they had.

Frisch's breakthrough publications, among them Statistical Confluence Analysis by Means of Complete Regression Systems (1934b), created the possibility of developing a macro-economic quantitative model (see also Frisch 1934a, 1933). In it, he described the way in which the (then) very new technique of multiple regression analysis could be used to estimate the parameters in systems of equations. Such a system of equations describing an entire (national) economy was first presented by Tinbergen (1935). His work showed full awareness of the quantitative challenges involved in estimating such a model (a word that Tinbergen now explicitly used), and it relied heavily upon Frisch's work from the year prior. But, it was not until 1936 that Tinbergen actually estimated a model for the Dutch economy based on statistical data of the past decade (Tinbergen 1936).

The theoretical developments followed each other quickly in these crucial formative years in econometrics. What both men were developing was not merely a quantitative model of the macro-economy (a word that

\footnotetext{
${ }^{8}$ Frisch to Tinbergen, 4 January 1934.
} 
did not even exist two years prior); but, it was a model that incorporated as best as possible an endogenous business cycle mechanism-one that, moreover, could be used in policy or even planning of the economy (Frisch 1934a).

Based on the success of his Dutch model, Tinbergen was invited to write a prestigious report on business cycles for the League of Nations (Tinbergen 1939a, 1939b). It was a demanding project to which many other leading economists contributed. But for Tinbergen, the most important interlocutor was Frisch. During an expert meeting in 1937 the draft of Tinbergen was discussed. In attendance were Francois Divisia, Erik Lundberg, Jacob Marschak, Arthur Bowley, Roy Harrod, Dennis Robertson, and Tjalling Koopmans. ${ }^{9}$ They would soon be, or already were, pioneers of the new economics. Frisch promised to join as well but cancelled because he was too busy working on his own project on the measurement of utility. ${ }^{10}$ His memorandum, now famous, on Tinbergen's draft report arrived two days after the expert meeting, much to the chagrin of Robertson and Loveday who jointly oversaw the project. ${ }^{11}$

Tinbergen, however, knew how much of his project was built on the foundations developed by Frisch and decided to plan a trip up north from his temporary stay in Geneva. Not only the multiple correlation was drawn from Frisch, but also an estimation technique known as bunch maps (Hendry and Morgan 1995). A big obstacle for any extensive quantitative analysis at this point in time was calculation power, which was still a completely manual process (with the help of a slider). So, any technique that allowed one to explore the data, or to (pre-)estimate certain relationships before doing the full calculation was more than welcome.

The memorandum of Frisch praised Tinbergen's work as possibly the greatest breakthrough in business cycle research-a possibly gratuitous compliment, since he was aware of the Dutch model which contained the same techniques-but it also heavily criticized the results. Frisch worried about the autonomy of the relationships (another term he coined): autonomy refers to the degree of independence of relationships from changes in the institutional or policy structure. The degree of independence from policy changes was important to both of their projects, since they were still primarily interested in the formulation of better economic policy. If a certain relationship, believed to be crucial, breaks down with a change

\footnotetext{
${ }^{9}$ Memorandum, League of Nations Archive, Series 32649, Code R, Box 4454, Document 36596.

${ }^{10}$ See their correspondence in September 1937.

${ }^{11}$ League of Nations Archive, Series 12653.
} 
in policy then the findings are of little use. But even aside from policy considerations, the autonomy of relationships is important from a scientific perspective. The goal is to arrive at generalizable models that can be used both over time and across space. If the findings are too dependent on the particular (historical) circumstances they are of little use in uncovering stable causal mechanisms. ${ }^{12}$

It was not so much the critical nature of the memorandum that demonstrated a somewhat growing divergence. Tinbergen was more than interested in Frisch's criticisms, as became clear from his desire to include the Frisch memorandum as a preface to the second volume of his study. But, whereas Tinbergen's approach was more and more pragmatic and aimed at practical results, in part driven by the worsening political and economic circumstances of the 1930s, Frisch appeared to be increasingly committed to the scientific soundness of the method. The very fact that Frisch was absent from the expert meeting for the prestigious League of Nations to work on his measurement of utility book is indicative of this commitment. Previously, he had refused to cooperate with Tinbergen's plan to draw up a petition of the Econometric Society against war and in favor of peace. ${ }^{13}$

A very similar dynamic repeated itself in the years following WWII. Ragnar Frisch was appointed as member of the chair of a U.N. Sub-Commission on Employment and Economic Stability in 1947. Frustrated with the one-sided focus on inflation, he drew up several internal memoranda which sought to integrate different policies, the most important one of which was presented in the spring of 1949. This memorandum upset the way econometric modelling would be done (Andvig 1988; Dekker 2020, chap. 9; Dupont-Kieffer 2003; Bjerve 1995). Whereas econometric modelling in the pre-war period mainly aimed to explain movements in the past with the hope of predicting those of the future, econometric modelling after the war was explicitly designed to reach certain policy targets. Tinbergen had already attempted to model different policy scenarios in the 1930s: what would happen to the economy if the government decided for major public works, or for devaluation? But such explorations were limited to a few scenarios, with policies modelled as changes in the external environment or 'data' in the model. After the war, Frisch proposed to invert what was considered fixed and variable in the econometric models:

\footnotetext{
${ }^{12}$ Similar critiques are later voiced in the famous takedown of Tinbergen's report by Keynes (1939).

${ }^{13}$ Tinbergen to Frisch, 20 March 1936.
} 
in his decision model, so-called policy variables could be decided upon. These policy variables should be chosen such that so-called target variables (economic growth, unemployment rate) reach the desired level.

It was precisely this approach-although much more applied and with a variety of practical examples-that Tinbergen presented in his classic On the Theory of Economic Policy (Tinbergen 1952). The approach in Tinbergen's presentation was practical and easy to apply, and it demonstrated to policymakers what policy could, but also could not, achieve. Frisch, however, was unhappy with the approach. He argued that the goal should be a model that could be maximized based on an underlying social preference function. And a considerable portion of his efforts afterwards were directed at the discovery of such a social preference function. Frisch hoped that sophisticated interviewing techniques would allow him to develop a social preference function of those currently in government (Johansen 1974). Although in theory Tinbergen did not disagree with that goal, he was convinced that it was untenable in the medium run.

As Herbert Simon correctly observed, Tinbergen's approach was pragmatic and satisficing. If a set of targets had been established, he could check whether they could be simultaneously achieved (Simon 1976, 75). Frisch on the other hand was more ambitious scientifically and wanted an optimal policy, not merely a satisfactory policy. This difference was also evident in the way both wrote. Whereas for Frisch theoretical and scientific goals were primary, for Tinbergen policy goals were more important. This ensured that the relative impact of their contributions was rather uneven. Today, Frisch's memorandum is barely acknowledged, and most of the credit for the development of macroeconomic decision models goes to Tinbergen. ${ }^{14}$ Frisch appeared to be aware of his own perfectionism-in his work leading up to the decision models, he suggested: "you may even find that we are aiming at something which is too formidable to be practicable. However, we have been specializing in unsolvable problems of this type and rather like to play with them, and we certainly want to be optimistic even in the face of difficulties that seem formidable" (Frisch 1948, 367).

What might also explain part of the difference between the two men is that Tinbergen no longer primarily worked at an academic institute, but rather at a government planning agency. Frisch's pragmatic decision model was designed for the U.N., but as a contribution to econometrics it

\footnotetext{
${ }^{14}$ The idea was in the air around 1950, for example Guy Orcutt pointed in the same direction (Orcutt 1952).
} 
did not satisfy him. Tinbergen was increasingly less concerned with making contributions to science and more and more concerned with making contributions to society. In this setting, the imperfection of the decisionmodel approach based on a set of targets, rather than a comprehensive social preference function, was a feature, not a bug. Frisch, on the other hand, strongly argued for academic freedom in research (Frisch 1946).

This difference was also evident elsewhere. Tinbergen was in a position of control, or sometimes of influence, of a variety of crucial knobs to manipulate the Dutch economy. He was not only the director of the most important economic policy bureau but occupied several other key policy positions during the first postwar decade, including a prominent position in the socio-economic council. Frisch, at this time, similarly had great influence with his decision models on Norwegian policymaking and the relevant policy institutions (Bjerve 1995, 13-15). Nonetheless, Frisch remained restless and soon suggested that the method of target-setting was primitive. He wanted a more comprehensive optimization method, but it proved a step too far for policymakers. Although his extraordinary expertise was recognized, as it had been by the League of Nations, his advice was considered to be somewhat abstract and too little concerned with political constraints. The League of Nations memorandum was internally criticized for bordering on the pedantic. Dennis Robertson wrote to Loveday that he "couldn't make much of the Frisch' portentous document!". ${ }^{15}$ It mostly discussed general results of Frisch, and only briefly cared to relate these to Tinbergen's study. This pattern repeated itself in interactions between the Norwegian government and Frisch (Bjerkholt 1995, 26).

\section{INTERNATIONAL INTERESTS}

Nonetheless, as if their lives were fully in sync, the early 1950s marked the moment that both Tinbergen and Frisch moved away from national concerns and moved into development economics. In both Egypt and India they did important work, although not much of it together. Both men shared an admiration for the prime minister of India, Jawaharlal Nehru. He was a strong believer in the importance of the use of statistics and planning techniques in the newly independent state of India and invited many Western economists to his country. Not insignificantly, he also founded the union of non-committed countries, which sought to find an

\footnotetext{
${ }^{15}$ Robertson to Loveday, 25 August 1938, League of Nations Archive.
} 
own development path that was neither capitalist (United States) nor communist (Soviet Union). It was a vision that was much to the liking of Tinbergen and Frisch who both in their own ways believed that Western Europe should provide an alternative model to these two extremes. Ever since the 1930s they had thought of their own planning techniques as a middle ground between the two systems.

In this spirit, Tinbergen and Frisch were both interested in the construction of a method of planning that was more coordinative than comprehensive. As Nehru put it: "of course, no plan can have finality in a moving and changing world, but anyhow one must have some ground to stand and to work upon and we hope that that plan will give us that standing room or jumping off place" (Nehru 1952).

Tinbergen first visited the International Statistical Institute in 1951 and was deeply shocked by the living conditions of the poor in India. He remained in close contact with the people at the Institute and sought to arrange a prolonged stay. But in 1953 he finally heard, discreetly, from the United Nations that because of a lack of funds they could only send one expert to India. The candidate from another country, who remained unnamed in the letter, was Ragnar Frisch. ${ }^{16}$ It would take until 1956 that Tinbergen would finally spend some more time in India to work on development planning. That pattern would repeat a few years later when a planning expert had to be sent to Turkey. The reluctant Turkish government refused the proposed Norwegian candidate, and a few months later Tinbergen travelled to the country (Dekker 2020, chap. 12).

Around 1950, some differences between them were already visible, though nationally they occupied similar positions as the premier economists and economic policy experts of their respective countries. During the 1960s, the underlying differences became more visible. Frisch's theoretical models became ever more demanding in terms of both data and computation. It was precisely data and computation power (in the form of expertise) that were in short supply in the developing world; and although India was the exception to the rule in this respect, implementation still often required quick-and-dirty solutions, at the expense of theoretical soundness. With the rise of computers, Frisch became increasingly interested in realizing the dream of the 1930s of a full dynamic model of the economy (Bjerve 1995, 16-17). Tinbergen, on the other hand, was turning more and more away from pure theory. His contributions to the development literature were either about institutional design (Tinbergen 1958) or

\footnotetext{
${ }^{16}$ Donald B. Kennedy to Jan Tinbergen, 25 November 1953, Tinbergen Letters.
} 
smart estimation techniques that allowed one to do planning in the absence of data and a comprehensive theory of development (Tinbergen 1965). An example of this is the semi input-output method (Tinbergen 1966). Frisch, on the other hand, developed sophisticated techniques to optimize non-linear systems with his multiplex method, and later with his nonplex method (Bjerkholt 1995). Where Tinbergen introduced additional simplifying assumptions, Frisch sought to do without the need for simplifying assumptions, such as the linearity assumption.

Tinbergen and Frisch, however, were still united in their deep concern with the poor and in their beliefs that economics could do much to improve the world. Their work in developing countries was driven by a shared sense of responsibility and hopes for a more peaceful word. But, at the international level, there was also one important political difference between the two men. In 1963, Jan Tinbergen was invited to give the Wicksell lectures-all the more significant since Wicksell was the great intellectual hero of Ragnar Frisch. Tinbergen chose as his topic a long-standing difference between them (Tinbergen 1974): the official topic of his lecture series was whether the European Union is progressive or conservative, but the real theme was whether Norway (and Sweden) should join the European Union (Tinbergen 1963b).

Initially Tinbergen's lectures focused on economic matters. Tinbergen defined the essence of the European Economic Community (EEC) to be the elimination of national trade borders, which might over time come to include the harmonization of tax regimes and the integration of currencies. But it is not there that their true difference of opinions lies. The real question was the extent to which the EEC is a democratic entity, and moreover, whether the progressive and protestant forces would win out from the more conservative catholic forces, the so-called black forces. Tinbergen tried to identify some progressive trends in the social policies-a rather heroic task given the fact that General De Gaulle, who had recently come into power, represented the clear antithesis of such modern social and international policy to both Tinbergen and Frisch: "all of us hope that France will soon again show its real face-which, by democratic measures, is federalist" (Tinbergen 1963b, 38).

At the heart of the disagreement between Frisch and Tinbergen was the question whether the EEC can provide a credible alternative on the international scene. Could it fulfill the role of an exemplary model that can stand beside that of the United States and Russia, and thereby serve 
as an exemplar for the non-committed developing countries? Frisch remained unconvinced and believed that Norway as such better represented such an exemplar than the imperfect EEC. Tinbergen, on the other hand, believed that only a democratic EEC could provide a credible alternative. Norway had not joined the EEC, and would never join the (later) Union. Frisch actively contributed to the political debate surrounding this issue. He rejoiced when the Norwegians rejected membership in the 1972 referendum (Bjerkholt 1995).

But beneath the disagreement over the status of Europe was an underlying agreement. It was about the desire for a synthesis between the systems of East and West. Frisch suggested a joint Nobel Peace Prize for Kennedy and Khrushchev for the efforts they had made to decrease tensions between the East and the West. During the same period, Tinbergen launched his convergence theory, which argued for an optimal regime that took the best from both regimes (Tinbergen, Linneman, and Pronk 1966; Linneman, Pronk, and Tinbergen 1965). Although both men were committed democratic socialists, they believed that a truly stable and just world order should include the Soviet Union.

\section{AlternAtive ASPIRATIONS}

In a 1934 paper on circulation planning, Frisch writes: "we have here one of those cases-so frequent in economic practice-where it can be 'proved' by abstract reasoning that a solution is not possible, but where life itself compels us nevertheless to find a way out" (Frisch 1934a, 274). It seems that throughout their careers, however close Tinbergen and Frisch were in both vision and intellectual interests, they chose opposing sides when such problems presented themselves. Frisch tended to seek some theoretical way out of the problem. What could he do to make the unsolvable solvable? In his Nobel lecture he went so far as to suggest that it was human to do so: "deep in human nature is an almost irresistible tendency to concentrate physical and mental energy on attempts at solving problems that seem to be unsolvable. Indeed, for some kinds of active people only the seemingly unsolvable problems can arouse their interest" (Frisch 1976b, 2). ${ }^{17}$

Tinbergen's Nobel lecture, on the other hand, is a confident overview of the more recent developments in the field. It presented the modelling

\footnotetext{
${ }^{17}$ The Nobel lecture, which Frisch did not give in 1969, is an odd document lacking in structure, with (at best) a loose association and no conclusion at all.
} 
approach he and Frisch pioneered as a flexible tool that has been successfully applied in a wide variety of fields, and that has much further potential. There is a brief word of caution about mistaking the model for the real thing, but the overall story is one of confidence and belief. Models help us solve the most important problems in the world.

This has resulted over the decades in radically different publication patterns between Frisch and Tinbergen. Tinbergen published over 1,500 articles in academic and professional journals and at least thirty books, most of these written for the educated layperson. Frisch's most important results were often buried in memoranda that, although they circulated among the select few, never received general readership, not even within the economics profession. They were, however, equally numerous: between 1947 and 1964, 240 of such memoranda were published ranging from 2 to 250 pages (Bjerve 1995, 22). But, much important work was published in Norwegian and not translated until late in his life. Frisch was never satisfied with his own efforts and regarded virtually all his work as tentative: still falling short of perfection. Tinbergen regarded all his work as work-in-progress. When he published, it was just one phase in the development of an idea, after which others would respond, disagree, and improve. In one of his articles, he even joked that professor Frisch would undoubtedly over the years find something wrong with it.

Frisch's work on the social preference function led to frustrated efforts to uncover the preferences of politicians, despite his tiresome attempts to develop such functions (Johansen 1974, 48). And however much his search for a social preference function was motivated by scientific concerns, it also reflected his position outside of the political domain proper. Although he sought to have an influence on Norwegian economic policymaking, his main concern remained the decision to be optimal. This was perfectly justified from the perspective of the scientist, and his rejection of the target method in decision models was a clear critique of Tinbergen. But the logic of politics demands imperfect decisions in the present, not some ideal or optimal decision in the future. Hence, while Tinbergen was willing to develop tools to make practical choices and trade-offs, Frisch preferred to develop tools for making optimal decisions. Tinbergen developed the practical planning technique at the Dutch planning agency and wrote various manuals on development programming. Frisch, on the other hand, notoriously locked his assistants in the lab to finish the calculations. 
Despite such differences, many of their students followed quite similar trajectories. Many of Tinbergen's students went on to have posts at the intersection of politics and science, for example Johan Witteveen at the International Monetary Fund and as minister in the Dutch Government, or Jan Pronk as functionary at the United Nations and the first undersecretary of development co-operation of the Netherlands. Frisch's students at his own Institute often also went on to become high-ranking civil servants or ministers of finance (Bjerve 1995, 22).

Frisch could not hide his disdain later in life of some of Tinbergen's more practical solutions. They wrote to each other about development models and optimal growth rates, a theme to which Frisch returned in his essay on the co-operation between politicians and econometricians. In the article, he attacked Tinbergen's approach of setting a particular growth target and suggested that such a method should be replaced with an investigation into the preference function of the current government. He would present the relevant political decision-maker with a set of hypothetical scenarios and, based on the answers, would construct a preference function. Afterwards, the econometricians would use this preference function to arrive at an optimal policy. Although Tinbergen sometimes harbored such desires, in which the experts would be able to dictate the optimal policy, in practice he often settled for less ambitious strategies. Although Frisch's essay is supposed to be on the 'co-operation' between experts and politicians, it is clear that he seeks something closer to a technocratic system: "Their Excellencies, being intelligent persons, will understand the philosophy of the preference questions and the expert's study of the core, and will therefore acquiesce in a solution which is not quite what they like" (Frisch 1976a, 46). And then, Frisch drove his point home: parliament should be concerned with the formulation of a set of preferences. In that way, it would concentrate its efforts on the truly vital issues.

Tinbergen, although he too has been accused of technocratic tendencies, was much more successful in achieving co-operation with politicians. Sometimes this was against his will, as when the Central Planning Bureau of which he was a director between 1945 and 1955 was made less prominent in economic policymaking than he had hoped (Don 2019). But generally, he was well aware of the importance of the appropriate institutional position of policy advice within the polity (Tinbergen 1954), and the practical usefulness (and costliness) of particular methods was always on his mind. When he spoke to policymakers, he also showed awareness 
of the personal qualities one needed to convince politicians, especially in developing countries (Tinbergen 1963a). That awareness and his constant search for consensus both in science and economics worked to his advantage in the political and especially diplomatic arena. Frisch instead preferred a more polemical style, not uncharacteristic of scientific disputes.

The story of Tinbergen and Frisch is also one of how differences in personality can lead to subtle but important differences in one's approach to science. Both men sought to turn economics into a quantitative science, and both felt a deep social responsibility to make that science useful for society. But Frisch, the perfectionist, struggled to balance these two goals, and often ended up, willingly or unwillingly, sacrificing relevance for scientific demands. Tinbergen, the pragmatist, can easily be accused of sacrificing scientific rigor in favor of relevance. But it made him much more successful in the policy arena. These differences also had something to do with their respective personalities. Frisch was demanding of those around him and often unwilling to compromise. When he had missed a lecture, he would make up for it by giving double lectures which could take three uninterrupted hours. By the 1960s, he became frustrated that old fictitious beliefs were returning in government policies, a one-sided reliance on monetary policy instruments (Bjerve 1995, 25). He warned of a return to unenlightened plutocracy. It was perhaps a response to the perceived failure of his efforts to influence policy, but it also reflected an uncompromising stance about the position of econometric methods in politics.

Tinbergen, on the other hand, never tired of engaging different publics. Whether addressing policymakers, other economists, religious groups, or simply a small group of interested laymen, he was always willing to explain his views. He increasingly became a public intellectual, more so after his retirement. His tolerance and modesty suited him well on such occasions. Although he held equally strong views as Frisch, he virtually never engaged in disputes. In policy organizations, he was often asked to chair committees: it was trusted that he would be able to bring others together. That was also how he formulated his scientific goal, after receiving advice from his mentor Ehrenfest: conflicts or differences of opinion had to be formulated in a nobler way. One could demonstrate, for example, that if $a>b$ then scholar $A$ is right, and when $b>a$, scholar $B$ is right (Tinbergen 1979, 331). It was with this same spirit that he sought to 
overcome deep ideological differences such as those between the capitalists of the West and the socialists of the East.

It is tempting to believe that precisely for those who turned economics into a science, subjective and personal factors are of little relevance. But quite the opposite is true. For Tinbergen, the appeal of science was precisely that it provided grounds for finding a consensus. He hoped others would adopt his modelling technique in part because it would provide a neutral and objective ground for discussion. That ambition was driven by his political ideals. He had experienced plenty of socialist debates in the 1920s, which made him weary of dogma and ideology. Science provided a means to overcome such ideological differences, a hope embodied in his convergence theory. This was a theory about the optimal socio-economic regime, but it was equally an expression of hope that both the West and the East would come to realize that the differences between them were ultimately reconcilable. It was an attempt to start a conversation across deep ideological differences in the guise of scientific theory (Linneman in Jolink and Barendrecht-Tinbergen 1993, 115-116).

Frisch had equally high hopes of science and shared Tinbergen's political idealism, although he never formally joined the Labor Party. But he was more uncompromising in his pursuit of scientific endeavors, although he recognized that scientific knowledge too had its limits (Bjerkholt and Dupont-Kieffer 2010, 66-68). Science, for Frisch, was not only the most rational form of discussion, it also provided clear, or at least the best available, answers to some of the most difficult political questions. Frisch was convinced that scientific techniques should be the primary basis for political decision-making. In order to make this happen, it was of the utmost importance to perfect the techniques (Bjerve and Frisch 1971).

Tinbergen was happy to work with imperfect techniques if these proved more appropriate or more useful in the policy arena. But over time, he increasingly thought of his own position as that of someone providing guidance, and long-term perspectives. When Tinbergen wrote a visionary article favoring the convergence between East and West, Frisch responded enthusiastically. In the article, Tinbergen argued for stronger international institutions to strengthen the global (economic) order necessary to ensure a peaceful co-existence of East and West. He sketched a general framework consisting of political and socio-economic questions, which can serve as the basis for a shared discussion, concluding: "I repeat that the purpose of this article was to invite discussion" (Tinbergen 1964, 
20). Frisch responded in a letter to Tinbergen that he shared his vision and believed that his own work on a mathematical coalition preference function could be of much help in defining the concept of Co-Existence. ${ }^{18}$

At that point, they had pointed their hopes for the future in two different directions. Tinbergen hoped that by sketching out vistas for the future he could be most effective. He did so as chair of Development Decade II for the U.N., in his report for the Club of Rome, Reshaping the International Order (1976), and for the Dutch public in books like An Inhabitable Earth (Tinbergen 1970). He wrote to Frisch that: "I am less of a scientist than at any time and deeply involved in some sort of policy-making". ${ }^{19}$ Frisch on the other hand believed that by perfecting and extending his decision models he could be of more value. There was some symbolic significance that Frisch was absent when their joint Nobel Prize was handed out in 1969. The public face of their joint program was there to accept the Prize, the scientific pioneer was hidden from sight. Not for the first time in their long collaboration. Tinbergen was more than aware of that; he wrote to Frisch about the celebrations accompanying the Nobel Prize: "in Stockholm as well as in Uppsala we were much aware of your being the real man $[\mathrm{sic}]$ had to be thought of". ${ }^{20}$

\section{REFERENCES}

Andvig, Jens Christopher. 1988. "From Macrodynamics to Macroeconomic Planning: A Basic Shift in Ragnar Frisch's Thinking?” European Economic Review 32 (2-3): 495502.

Bjerkholt, Olav. 1995. Foundations of Econometrics: The Selected Essays of Ragnar Frisch. London: Edward Elgar.

Bjerkholt, Olav, and Ariane Dupont-Kieffer. 2010. "Ragnar Frisch's Conception of Econometrics." History of Political Economy 42 (1): 21-73.

Bjerve, Petter Jakob. 1995. "The Influence of Ragnar Frisch on Macroeconomic Planning and Policy in Norway." Statistics Norway Research Department 1995/10. Oslo.

Bjerve, Petter Jakob, and Ragnar Frisch. 1971. "Økonomisk Teori Og Okonomisk Politikk." In Okonomi Og Politikk, edited by Petter Jakob Bjerve, and Ole Myrvoll, 513. Oslo: H. Aschehoug \& Co.

Boumans, Marcel. 1992. A Case of Limited Physics Transfer: Jan Tinbergen's Resources for Re-Shaping Economics. Amsterdam: Tinbergen Institute.

Dekker, Erwin. 2020. An Economist Looking for Peace: The Life and Work of Jan Tinbergen (1903-1994). Cambridge: Cambridge University Press.

Don, Frans J. H. 2019. "The Influence of Jan Tinbergen on Dutch Economic Policy.” De Economist 167 (3): 259-282.

\footnotetext{
${ }^{18}$ Frisch to Tinbergen, 7 December 1964, Frisch Archives.

${ }^{19}$ Tinbergen to Frisch, 25 December 1969, Frisch Archives.

${ }^{20}$ Ibid.
} 
Dupont-Kieffer, Ariane. 2003. "Ragnar Frisch et l'économétrie: L'invention de Modèles et d'instruments à Des Fins Normatives." PhD dissertation, Paris 1.

Dupont-Kieffer, Ariane. 2013. "Mesure de l'utilité Marginale et Indice de Prix Chez Ragnar Frisch Le Difficile Mariage de La Théorie Économique et Des Instruments Statistiques." OEconomia 3 (1): 23-57.

Frisch, Ragnar. 1926a. "Kvantitativ Formulering Av Den Teoretiske Økonomikks Lover." Statsøkonomisk Tidsskrift 40: 299-334.

Frisch, Ragnar. 1926b. “Sur Un Problème D’Économie Pure.” Norsk Matematisk Forenings Skrifter Series I (16): 1-40.

Frisch, Ragnar. 1929. "Statikk Og Dynamikk i Den Økonomiske Teori." $\mathrm{Na}-$ tionaløkonomisk Tidsskrift 67: 321-379.

Frisch, Ragnar. 1932a. "Méthodes Nouvelles Pour Mesurer l'utilité Marginale." Revue d'Économie Politique 46 (1): 1-28.

Frisch, Ragnar. 1932b. New Methods of Measuring Marginal Utility. Tübingen: J.C.B. Mohr.

Frisch, Ragnar. 1933. Propagation Problems and Impulse Problems in Dynamic Economics. London: Allen \& Unwin.

Frisch, Ragnar. 1934a. "Circulation Planning: Proposal for a National Organization of a Commodity and Service Exchange." Econometrica 2 (3): 258-336.

Frisch, Ragnar. 1934b. Statistical Confluence Analysis by Means of Complete Regression Systems. Oslo: Universitetets Økonomiske Institut.

Frisch, Ragnar. 1936. "On the Notion of Equilibrium and Disequilibrium." The Review of Economic Studies 3 (2): 100-105.

Frisch, Ragnar. 1946. "The Responsibility of the Econometrician.” Econometrica 14 (1): $1-4$.

Frisch, Ragnar. 1948. "Repercussion Studies at Oslo." The American Economic Review 38 (3): 367-372.

Frisch, Ragnar. 1976a. "Co-Operation Between Politicians and Econometricians on the Formalization of Preferences." In Economic Planning Studies: A Collection of Essays, edited by Frank Long, 41-86. Dordrecht: D. Reidel Publishing Company.

Frisch, Ragnar. 1976b. "From Utopian Theory to Practical Applications: The Case of Econometrics." In Economic Planning Studies: A Collection of Essays, edited by Frank Long, 1-40. Dordrecht: D. Reidel Publishing Company.

Hanau, Arthur. 1928. "Die Prognose Der Schweinepreise." Vierteljahreshefte Zur Konjunkturforschung, no. Sonderheft 7.

Hendry, David F., and Mary S. Morgan. 1995. The Foundations of Econometric Analysis. Cambridge: Cambridge University Press.

Johansen, Leif. 1974. "Establishing Preference Function for Macroeconomic Decision Models: Some Observations on Ragnar Frisch's Contributions." European Economic Review 5 (1): 41-66.

Jolink, Albert, and Els Barendrecht-Tinbergen. 1993. Gedeelde Herinneringen. Rotterdam: Erasmus Universiteit Rotterdam.

Keynes, John Maynard. 1939. "Professor Tinbergen's Method.” The Economic Journal 49 (195): 558-577.

Klein, Martin J. 1958. "Ehrenfest Comes to Leiden.” Delta 5 (4): 5-14.

Linneman, Hans, Jan P. Pronk, and Jan Tinbergen. 1965. Convergence of Economic Systems in East and West. Rotterdam: Netherlands Economic Institute. 
Nehru, Shir Jawaharlal. 1952. “Address.” In International Statistical Conferences: December 1951 India, 12-18. Calcutta: EKA Press.

Orcutt, Guy H. 1952. "Toward the Partial Redirection of Econometrics.” The Review 34 (3): 195-200.

Simon, Herbert A. 1976. "From Substantive to Procedural Rationality." In 25 Years of Economic Theory: Retrospect and Prospect, edited by T. J. Kastelein, Simon K. Kuipers, W. A. Nijenhuis, and R. G. Wagenaar, 65-86. Boston, MA: Springer.

Tinbergen, Jan. 1925. "Wiskunde - Grenswaarde - Marx.” Kentering 1 (5): 65-68.

Tinbergen, Jan. 1930. "Mathematiese Psychologie.” Mensch En Maatschappij 6: 342-352.

Tinbergen, Jan. 1933. "The Notions of Horizon and Expectancy in Dynamic Economics." Econometrica 1 (3): 247-264.

Tinbergen, Jan. 1935. "Quantitative Fragen Der Konjunkturpolitik." Weltwirtschaftliches Archiv 42: 366-399.

Tinbergen, Jan. 1936. "Kan Hier Te Lande, Al Dan Niet Na Overheidsingrijpen, Een Verbetering van de Binnenlandse Conjunctuur Intreden, Ook Zonder Verbetering van Onze Exportpositie?" In Prae-Adviezen Voor de Vereeniging Voor de Staatshuishoudkunde En de Statistiek, 62-108. Den Haag: Nijhoff.

Tinbergen, Jan. 1939a. Statistical Testing of Business-Cycle Theories. Part I: A Method and Its Application to Investment Activity. Geneva: League of Nations Economic Intelligence Service.

Tinbergen, Jan. 1939b. Statistical Testing of Business-Cycle Theories. Part II: Business Cycles in the United States of America 1919-1932. Geneva: League of Nations Economic Intelligence Service.

Tinbergen, Jan. 1952. On the Theory of Economic Policy. Amsterdam: North Holland.

Tinbergen, Jan. 1954. Centralization and Decentralization in Economic Policy. Amsterdam: North Holland.

Tinbergen, Jan. 1958. The Design of Development. Baltimore, MD: The Johns Hopkins Press.

Tinbergen, Jan. 1963a. "Economic Planning for Development." In Ambassadors Days at the Netherlands Trade Promotion Centre, edited by S. J. van den Bergh, 8-12. The Hague: Netherlands Trade Promotion Centre.

Tinbergen, Jan. 1963b. The European Community: Conservative or Progressive? Stockholm: Almqvist \& Wiksell.

Tinbergen, Jan. 1964. “Concrete Concepts of Co-Existence.” Co-Existence 1 (1): 15-20.

Tinbergen, Jan. 1965. "Simple Devices for Development Planning." In Problems in Economic Development: Proceedings of a Conference Held by the International Economic Association, edited by E. Austin G. Robinson, 373-390. London: Macmillan and Co.

Tinbergen, Jan. 1966. "Some Refinements of the Semi-Input-Output Method." The Pakistan Development Review 6 (2): 243-247.

Tinbergen, Jan. 1970. Een Leefbare Aarde. Amsterdam: Agon Elsevier.

Tinbergen, Jan. 1974. "Ragnar Frisch's Role in Econometrics: A Sketch.” European Economic Review 5 (1): 3-6.

Tinbergen, Jan. 1976. Reshaping the International Order: A Report to the Club of Rome. New York, NY: New American Library.

Tinbergen, Jan. 1979. "Recollection of Professional Experiences.” PSL Quarterly Review 32 (131): 331-360. 
Tinbergen, Jan. 2003. Jan Tinbergen: The Centennial Volume. Edited by Jacob Kol. Rotterdam: Erasmus Universiteit Rotterdam.

Tinbergen, Jan, Hans Linneman, and Jan P. Pronk. 1966. “The Meeting of the Twain.” The Columbia Journal of World Business 2 (1): 139-149.

Erwin Dekker (1984) is a post-doctoral researcher at the Erasmus School of Economics, and has been a post-doctoral fellow at the Mercatus Center at George Mason University. He is currently finishing the intellectual biography of Jan Tinbergen, the first Nobel Prize winner in Economics; the biography An Economist Looking for Peace will be published in 2020 by Cambridge University Press. His book The Viennese Students of Civilization (2016) on the cultural context of the Austrian school of economics was published by Cambridge University Press. His research focuses on the intersection of art, culture and economics. He has published articles in the fields of cultural economics, Austrian economics, economic methodology and intellectual history. He is currently working on a book project about the way in which knowledge commons sustain and facilitate markets.

Contact e-mail: <e.dekker@eshcc.eur.nl> 